David L. Dull MD, Robert B. Forbes MD, John H. Tinker MD

\title{
Efficacy of prior skin puncture in preventing iv catheter damage
}

The efficacy, with respect to preventing iv catheter damage, of creating a skin entry site by first piercing the skin with a large gauge needle through which an over-the-needle teflon catheter is then placed was evaluated. In 50 adult volunteers two 22-gauge iv catheters and two 24-gauge catheters were placed through the forearm skin into the subcutaneous tissue. One catheter of each size was placed through an entry site created by piercing the skin with an 18-gauge disposable, stainless steel needle. One catheter of each size was inserted through nearby skin without creation of an entry site. Two to three weeks after insertion all catheters, along with 50 catheters of each size that had not been inserted, were examined under a microscope for evidence of damage. Intravenous catheter damage was more prevalent in the 24-gauge catheters than the 22 -gauge catheters $(P<0.05)$. No differences in frequency of damage were noted for either gauge catheter inserted through an entry site compared with those inserted without a prior skin puncture. Twenty-four-gauge catheters, but not 22-gauge catheters, placed into the subcutaneous tissue were damaged more frequently than were catheters that had never been inserted (control catheters). This study demonstrated that 24-gauge catheters are more likely to be damaged during insertion into the subcutaneous tissue than are 22-gauge catheters. We also demonstrated that creation of a skin entry site by piercing the epidermis with a needle of larger gauge than the catheter to be. placed is not efficacious in preventing intravenous catheter damage during insertion.

L'efficacité, concernant la prévention de dommage au cathéter intraveineux, par la création d' un site d'entrée d travers la peau par la poncrion au préalable avec une aiguille de grand calibre. d̀ travers lequel un cathéter de teflon sur une aiguille métallique est placé ultérieurement, a été évaluée. Chez 50 volontaires

\section{Key words}

EQUIPMENT: catheters, intravenous.

From the Department of Anesthesia, University of lowa College of Medicine, Iowa City, IA 52242.

Address correspondence 10: Dr. David L. Dull, Department of Anesthesia, University of Iowa College of Medicine, Iowa City, IA 52242.

Accepted for publication 24th September, 1990. adultes deux cathéters intraveineux calibre 22 et deux cathéters calibre 24 seraient placés à travers la peau de la membrane dans le tissu sous-cutané. Un cathéter de ce calibre fut placé à travers un site d'entrée créé par la ponction de la peau avec une aiguille métallique disposable de calibre 18. Le cathéter de chaque calibre fut inséré à travers la peau avoisinante sans la création des sites d'entrée. Deux à trois semaines aprés l'insertion de tous les cathéters et 50 cathéters de chaque calibre qui ne furent pas installés, furent examinés sous microscope pour mettre en évidence les dommages. Les dommages aux cathéters intraveineux étaient plus fréquents pour les cathésers de calibre 24 que ceux de calibre $22(P<0.05)$. Alucune différence ne fut notée concernant le dommage aux cathéters insérés à travers un site d'entrée comparé à ceux insérés sans site d'entrée. Les cathéters de calibre 24, mais non ceux de calibre 22 placés dans le tissu souscutané démontraient un dommage plus fréquenunent que les cathéters qui n'ont jamais été insérés (cathéters contrôle). L'étude démontre que les cathéters de calibre 24 étaient plus susceptibles aux dommages lors de l'insertion dans le tissu souscutané que ceux de calibre 22. On a aussi démontré que ln création d'un sile d'entrée à travers la peau par la perforation de l'épiderme avec une aiguille plus grosse que le cathéter n'était pas efficace pour prêvenir les dommages aux cathéters lors de l'insertion.

In recent years there has developed an increased awareness that inadvertent needle punctures with contaminated needles pose a health risk to health care providers. These concerns have led to recommendations that workers wear gloves when handling body fluids, that needles not be recapped, and that health care workers limit exposure to contaminated objects. ${ }^{1-5}$ Despite these concerns, textbooks of anaesthesia and critical care medicine recommend that the skin be punctured with a needle of larger gauge than the catheter to be placed prior to attempting to place an over-the-needle intravenous catheter into a vein or an artery, ${ }^{6-11}$ This recommendation results in the presence of an additional contaminated needle in the anaesthetist's work area, perhaps increasing the risk of an inadvertent needle puncture by a health care worker. One reason commonly cited for this recommendation is that it decreases the incidence of catheter damage resulting from passage of the catheter through the epidermis. ${ }^{6,7,10,11}$ 
We were unable to find documentation in the literature of the efficacy of this commonly used procedure, which results in the use of an extra needle, in preventing catheter damage. Therefore, the purpose of this study was to evaluate the efficacy of prior skin puncture in preventing damage to over-the-needle teflon intravenous catheters during passage of the catheter through the skin.

\section{Methods}

Before initiation of this sludy approval was obtained from the hospital Human Subjects Review Committee. After obtaining informed written consent, both forearms of 50 adult volunteers were washed using alcohol. At a predetermined location $15 \mathrm{~cm}$ proximal to the styloid process of the radius along a line connecting the medial epicondyle of the humerus and the styloid process of the radius on the anterior surface of each forearm, 1\% lidocaine was injected using a 25 -gauge needle to create an intradermal skin wheal. In the area anaesthetized with local anaesthetic, a cutting bore, stainless steel (B-D ${ }^{\circledR}$ ) 18-gauge needle was inserted through the epidermis to produce a small skin puncture. Through this skin puncture a randomly chosen, numbered, Jelco ${ }^{\circledR} 22$-gauge over-theneedle catheter was inserted with free passage into the subcutaneous tissue. Near the above site, a second Jelco ${ }^{(1)}$ 22-gauge iv catheter was placed through the epidermis into the subcutaneous tissue without a prior skin puncture. Both catheters were removed, capped and stored for later examination. On the opposite forearm the procedure was repeated using two 24-gauge Jelco ${ }^{\circledR}$ over-the-needle iv catheters. In all cases the catheters were placed with the inner stylet in place. All needles and catheters were inserted at an angle of 15-30 degrees to the skin surface, and with the bevel up. All catheters, along with 50 unused stylev/catheter units of each size, were later examined for evidence of damage by a blinded observer using a 41 power microscope. Damage was defined as obvious disruption of the catheter, specifically, tearing of the catheter, peeling of the catheter away from the stylet or evidence of longitudinal compression of the catheter. Analysis of the results was carried out using Chi squared testing and Fisher's exact test. Significance was accepted at $P<0.05$.

\section{Results}

Overall catheter damage occurred more frequently with 24-gauge catheters than with 22 -gauge catheters $(P<$ 0.05 ). Of the one hundred 22-gauge catheters inserted eight were damaged compared with 24 damaged 24-gauge catheters out of a total of 100 inserted (Figure 1).

Five 22-gauge catheters placed through a skin puncture were damaged compared with three 22-gauge catheters damaged when placed without a prior skin puncture.

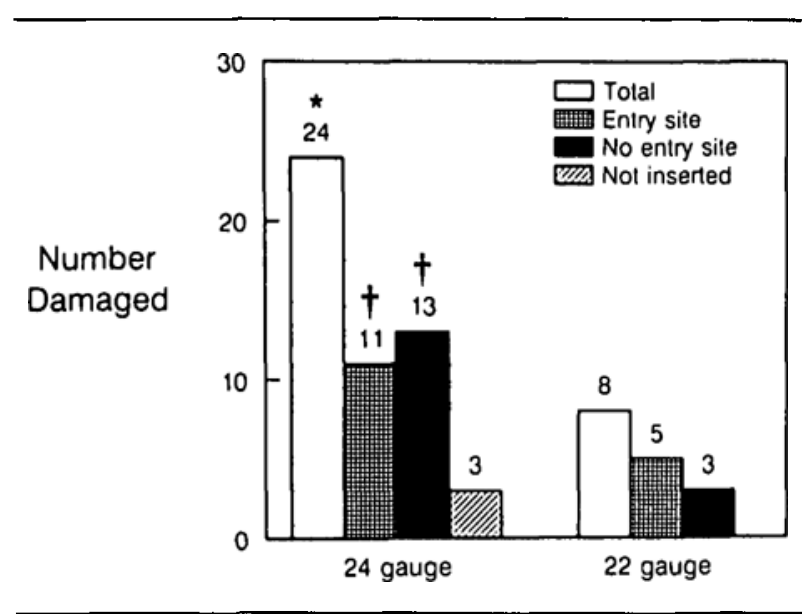

FIGURE 1 Number of damaged iv catheters. ${ }^{*} P<0.0524$-gauge catheters vs 22 -gauge catheters. $+P<0.0524$-gauge catheters inserted vs control catheters.

There were no damaged catheters in the 22-gauge control group. These differences were not significant (Figure 1).

When 24-gauge catheters were evaluated, there was no difference in the incidence of damage between the group of 24-gauge catheters inserted through a skin puncture site versus those inserted without creation of a skin entry site. Eleven catheters were damaged in the group inserted through skin entry site compared with 13 damaged catheters in the group inserted without a skin entry site (Figure 1). In the control group of 24-gauge catheters three were noted to be damaged. However, more 24-gauge catheters were damaged in both the group of catheters inserted through a skin entry site and those inserted without creation of an entry site compared with the control 24-gauge catheters $(P<0.05)$ (Figure 1).

Catheter damage noted consisted of the distal portion of the catheter being peeled back from the stylet (Figure 2).

\section{Discussion}

The first over-the-needle iv catheters were introduced in November 1949 at the Mayo Clinic by David Massa MD and were named "Rochester Plastic" needles. They consisted initially of a metal hub cut from a needle through which a smaller needle was placed and over which a length of polyethylene tubing was stretched. ${ }^{12,13}$ Catheters were cut to length off rolls of tubing. As a result, there was a distinct shoulder at the junction of the stylet and the catheter. Because of the soft, pliable nature of the polyethylene and the distinct shoulder present on the original Rochester needles they were easily damaged during insertion. Usually the damage consisted of the catheter folding back on itself, in an accordion-like fashion, during passage through the skin. To eliminate this problem William Pender MD began puncturing the skin with a Lundy awl or a needle prior to attempting 


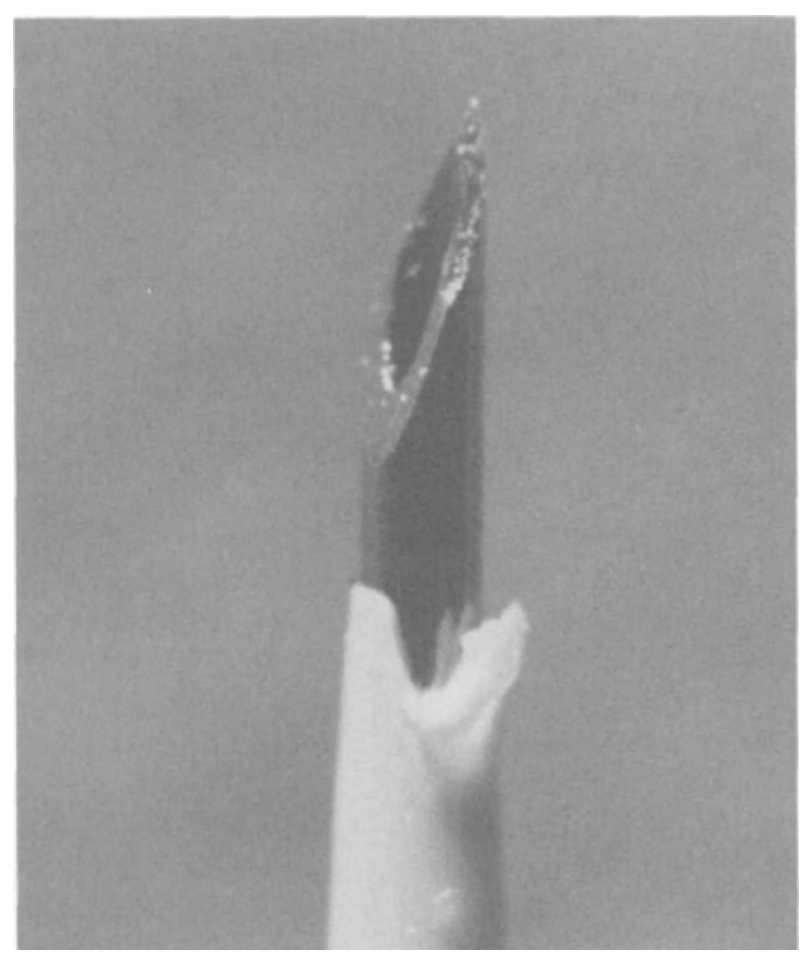

FIGURE 2 Catheter damage representative of damage noted in study catheters.

catheter placement.* This practice has persisted to the present despite considerable improvement in the design of over-the-needle intravenous catheters.

This study has demonstrated that piercing the skin prior to placement of an iv catheter with a larger gauge needle than the catheter to be placed does not reduce the incidence of catheter damage during insertion of 22- or 24-gauge over-the-needle teflon catheters into human subcutaneous tissue. For the 22-gauge catheters there was no difference in damage between any of the groups examined. For the 24-gauge catheters there was no difference in the incidence of damage between the catheters inserted through a skin puncture site and those inserted without benefit of a prior skin puncture. However, the incidence of damage was significantly greater in both of the above groups of 24-gauge catheters compared to the incidence of damage in the group of unused 24-gauge catheters. This finding indicates that 24-gauge catheters were damaged during insertion but that epidermal puncture was ineffective at decreasing the incidence of damage. Finally, this study demonstrated that 24-gauge catheters were more frequently damaged than 22-gauge catheters.

*Massa, D. Personal communication, December 13,1989, Lexington, Ohio.
Inherent in this study are several limitations. First, only one brand of catheter/stylet units was evaluated. It is conceivable that different results would have been obtained if more than one brand of catheter had been tested. However, since modern catheter/stylet units are very similar, this possibility seems unlikely.

Second, only 22- and 24-gauge catheters were evaluated. It is conceivable, although we are not aware of evidence to support this contention, that larger catheters are more susceptible to damage than the smaller gauge catheters tested. Thus, inclusion of large gauge catheters might have altered the results. Our results would in fact suggest the opposite to be true.

Third, this investigation was carried out on healthy adult volunteers in whom no attempt was made to cannulate veins or arteries. It is possible that the incidence of damage would be different if a paediatric population had been tested or if intravenous and intra-arterial placement had been attempted. However, since adult skin tends to be more cornified than the skin of small children it seems unlikely that inclusion of children in the study group would have significantly altered our findings. Inclusion of only adults should, if anything, accentuate the efficacy of needle puncture in preventing catheter damage. Additionally, since the needle puncture is only made through the superficial skin it is unlikely that insertion of both groups of catheters into a blood vessel would have altered our findings.

Fourth, it is possible that the angle of needle and catheter insertion and the direction of the bevel is important in production of catheter damage. The angle of insertion and bevel direction were chosen to simulate conditions of intravenous catheterization practiced at our institution.

Fifth, in this study only the issue of catheter damage was addressed. Other reasons cited for puncturing the skin prior to placement of over-the-needle catheters, including improved ability to discern blood vessel entry by the catheter or decreased incidence of stylet plugging during insertion were not evaluated. ${ }^{8}$

In summary, this study has demonstrated that 24-gauge catheters are damaged more frequently than 22-gauge catheters during placement. It has also demonstrated that puncturing the skin with a large gauge needle prior to placement of these over-the-needle catheters is not efficacious in preventing catheter damage.

\section{References}

1 Stoelting $R K$. Anesthesia and Co-Existing Disease. New York: Churchill Livingston, 988; 662.

2 CDC. Recommendations for preventing transmission of infection with human T-lymphotropic virus type 
UV/ymphadenopathy-associated virus in the work-

place. MMWR 1985; 34: 681-95.

$3 C D C$. Recommendations for preventing transmission of infection with human T-lymphotropic virus type III/ lymphadenopathy-associaled virus during invasive procedures. MMWR 1985; 35: 221-3.

$4 C D C$. Recommendations for prevention of HIV transmission in health-care settings. MMWR 1987; 36: 3s-18s.

5 Kunkel SE, Mamer MA. Human T-lymphotropic virus type III (HTLV III) infection: how it can affect you, your patients and your anesthesia practice. Anesthesiology 1987; 68: 195-207.

6 Gregory GA. Pediatric Anesthesia. New York: Churchill Livingston, 1988; 548.

7 Cook DR, Marcy JH. Neonatal Anesthesia. Pasadena, California: Appleton Davis, 1988; 156.

8 Rogers $M C$. Textbook of Pediatric Intensive Care. Baltimore, Maryland: Williams and Wilkins, 1987; 1407.

9 Steward DJ. Manual of Pediatric Anesthesia. New York: Churchill Livingston, 1985; 70.

10 Gravenstein JS. Paulus DA. Clinical Monitoring Practice. Philadelphia, JB Lippincott, 1987; 77.

11 Stoelting $R K$, Miller RD. Basics of Anesthesia. New York, Churchill Livingstone, 1989; 218.

12 Massa DJ, Lundy JS, Faulconer A Jr, Ridley RW. A plastic needle. Proc Staff Meet Mayo Clin 1950; 24: 413-5.

13 Massa DJ. A plastic needle. Anesthesiology 1951; 12: 772-3. 